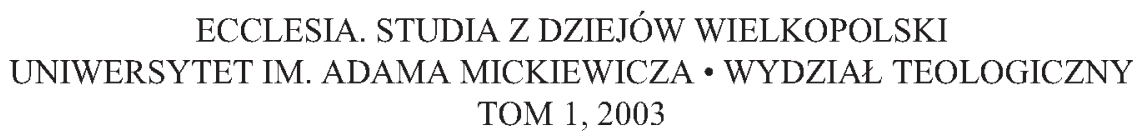

FELIKS LENORT

\title{
Przypomnienie otwarcia nowego Seminarium Duchownego w Poznaniu w roku 1896
}

Dekret Soboru Trydenckiego Cum adolescentium aetas z 15 lipca 1563 roku zobowiązujący biskupów do założenia w swych diecezjach seminariów duchownych odegrał niewątpliwie przełomową rolę w dziejach kształcenia i formowania kandydatów do kapłaństwa. W sytuacji nowych zadań Kościoła wynikających z rozszerzania się ruchów reformacyjnych, dotychczasowe formy kształcenia i edukacji duchowieństwa okazywały się niewystarczające.

Przed diecezjami stanęło więc poważne wyzwanie zarówno w rozumieniu organizacyjnym, kadrowym (używajac dzisiejszej terminologii), jak i nie mniej ważny problem znalezienia lub pobudowania odpowiednich pomieszczeń, domu $w$ pobliżu katedry lub $w$ innym stosownym miejscu, obranym przez biskupa (słowa wymienionego dekretu).

W Poznaniu już w rok po ogłoszeniu dekretu Cum adolescentium aetas, 26 października 1564 podjął synod diecezjalny uchwałę o konieczności założenia seminarium duchownego. Sytuacja była tu jednak nieco odmienna w stosunku do innych stolic biskupich. Tutaj bowiem od roku 1519 istniała już Akademia, założona przez biskupa Jana Lubrańskiego. Wydawało się rzeczą naturalna, iż to w ramach tej Akademii, dla której wybudowano odrębny gmach (ukończony w roku 1528) winno się odbywać kształcenie duchowieństwa, co mogłoby zadość uczynić trydenckiemu dekretowi. Inicjatywa ta jednak, mimo powołania przy Akademii alumnatu, okazała się nietrwała.

Gdy w roku 1571 przybyli do Poznania jezuici, otworzyła się przed seminarium duchownym nowa perspektywa. To im właśnie postanowiono powierzyć kształcenie diecezjalnego duchowieństwa, powołując równocześnie seminarium przy jezuickim kolegium. W zamiarze biskupa Adama Konarskiego seminarium to miało się mieścić w obszernym domu w pobliżu katedry. Jezuici jednak chcieli 
mieć kolegium w środku miasta. Biskup przystał na to i przekazał im kościół świętego Stanisława z przyległościami, co miało umożliwić przyszłą rozbudowę. Dla alumnów diecezjalnych została przeznaczona kamienica w pobliżu jezuickiego kolegium przy ul. Butelskiej (dzisiejsza ul. Woźna). Wciąż jednak trwały usiłowania biskupa, by seminarium jednak przenieść w pobliże katedry. Chcąc ten zamysł zrealizować biskup Andrzej Opaliński w roku 1607 rozpoczą prace nad odnowieniem stuletnich już, podniszczonych budynków Akademii Lubrańskiego i po ich zakończeniu w roku 1614 seminarium zostało istotnie przemieszczone w pobliże katedry, o co nieustannie zabiegała kapituła (umowa z jezuitami ustała). Opróżniony gmach seminaryjny przy ul. Butelskiej został zrazu wydzierżawiony, a w roku $1616 \mathrm{z}$ polecnia biskupa sprzedany.

Gdy w roku 1619 ponownie uruchomiono Akademię i jej gmach przeznaczono w części na mieszkania dla profesorów a w części na bursę studencką seminarzystów stamtąd wyprowadzono. Przeniesiono ich do domu dawnej szkoły katedralnej u wylotu ul. Wikariuszowskiej (dzisiejszej ul. Lubrańskiego). Seminarium zajęło wprawdzie dom piętrowy, ale skromniejszy (na parterze sale wykładowe, na piętrze szereg małych pokoi dla alumnów).

W czasie najazdu szwedzkiego w roku 1655 dom seminaryjny, w którym mieściło się wówczas kilkunastu alumnów, opustoszał zupełnie. W roku 1669 ponownie zamieszkał w nim jeden alumn, z czasem drugi. W roku 1666 kapituła - widząc, iż dom ten ulega coraz poważniejszym zniszczeniom - zwróciła się do biskupa Stefana Wierzbowskiego z prośbą o wznowienie seminarium od duższego czasu opustoszałego. Ale biskup Wierzbowski na stałe już rezydujący w Warszawie, bardziej był zainteresowany mazowiecką częścią swej diecezji i tamtejszym seminarium, prowadzonym przez księży misjonarzy. Dzięki jednak wysiłkom kapituły dom seminaryjny został ponownie uruchomiony w roku 1676, odtąd pod zarządem Akademii (bezpośrednią piecze sprawował jeden z profesorów). Sytuacja ta trwała do roku 1780, a więc do kasacji Akademii.

Od roku 1784 dawny gmach Akademii biskup Antoni Onufry Okęcki oddał ostatecznie na wyłączne cele seminarium duchownego, a jego kierownictwo zlecił księżom misjonarzom (tak było do roku 1834, gdy księża misjonarze na żądanie władz pruskich musieli zrezygnować z kierowania seminarium).

Od roku 1835 rozpoczyna się nowy okres w dziejach seminarium poznańskiego. Rząd pruski, kierując się zamiarami germanizacyjnymi, dążył do tego, by alumni studiowali na Uniwersytecie Wrocławskim, a na miejscu, w Poznaniu, odbywali jedynie roczne studium teologii praktycznej. Miano nawet dla nich wybudować konwikt we Wrocławiu na koszt państwa pruskiego (wyznaczono sumę 16.500 talarów, która to suma okazała się bardzo szczęśliwa, gdy podjęto myśl budowy seminarium $z$ prawdziwego zdarzenia, dzisiejszego). Kilka lat trwały spory o lokalizację tego rządowego pomysłu. W końcu arcybiskup Marcin Dunin uznał pomyst 
kształcenia alumnów poza diecezją (i w konsekwencji zbudowania tam konwiktu) za sprzeczny z bullą De salute animarum (1821), która w państwie pruskim miała range prawa państwowego.

Ponieważ liczba alumnów rosła (w roku 1857 osiagnęła 114), seminarium w gmachu Akademii Lubrańskiego nie mogło wszystkich pomieścić. W roku 1858 został opracowany plany budowy trzeciego piętra, aby wygospodarować tam nowe pokoje dla alumnów, ale plan ten niebawem zarzucono. Tylko w niewielkim stopniu zaradziło tej sytuacji umieszczenie części kleryków w Karmelu (dom po zniesionym klasztorze). Dodać trzeba, że część kleryków mieszkała także w trzech domach na Zagórzu. Ksiądz Władysław Chotkowski naówczas alumn, wspominał po latach: Co to byty za domy! Piszacy mieszkat (we trzech) na strychu w matym pokoiku, którego podloga wygięta byla w palak $i$ grozila lada chwila zawaleniem. Jaki mógt być nadzór przy takim rozproszeniu kleryków. Wyktady odbywaty się w ciasnej, dlugiej i tak waskiej sali, że klerycy musieli iść gęsiego pomiędzy lawkami, żeby się dostać do miejsc swoich.

Coraz bardziej oczywiste stawało się przeświadczenie o konieczności budowy gmachu seminaryjnego z prawdziwego zdarzenia. Dzieło to - jak się później okazało - miało być związane na trwałe z osoba arcybiskupa Floriana Stablewskiego, który w roku 1891 objął rządy nad archidiecezją gnieźnieńską i archidiecezją poznańską. Arcybiskup niezwłocznie zainteresował się swoimi seminariami w Gnieźnie i Poznaniu. To drugie było zdecydowanie w gorszym stanie. Musiał już być w tej sprawie dobrze zorientowany skoro w liście do kardynała Ledóchowskiego z 11 czerwca roku następnego uznał za stosowne wspomnieć o fatalnych warunkach mieszkaniowych alumnów, że jest ich 85, ale musiał ich jak śledzie popakować, że jest im duszno i ciasno, że nie może z tego powodu przyjać wszystkich zgłaszających się kandydatów.

Postanowienie o budowie zapadło. Trzeba było rozwiązać - co zrozumiałe wiele poważnych problemów, w tym zebrać przecież potrzebne fundusze. Niespodziewanie w sukurs przyszedł fundusz wrocławski, szczęśliwie wtedy niewykorzystany. Wspomniany wyżej ksiądz Władysław Chotkowski, świadek tego czasu, plastycznie opisał to kilkanaście lat później na łamach krakowskiego "Czasu” (w formie książkowej wydane w Poznaniu w roku 1906).

Arcyb. Stablewski naglił u rzadu o pieniqdze na seminaryum i kut żelazo, póki bylo gorace, ale rzecz szła jak z kamienia. Rzad pieniędzy nie mial i nie miat; mijal już rok piaty, nadzieja byla coraz stabsza. Pomogła gościnność Arcybiskupa. Brano mu za złe $i$ to gościnne podejmowanie, ale $i \mathrm{w}$ tem pokazal rozum. Zaproszono razu pewnego radzcę rejencyjnego. Arcybiskup skierowat rozmowę na potrzebę seminarium na to, ze rzad zastania się brakiem funduszów, a gość na to: Wtaściwie powinniby dać na ten cel «Konwiktsfond». Wymówiwszy to, zlakt się i pobladl, ale Arcybiskup nie zdradzit 
się z tem, że pierwszy raz w życiu o tym funduszu ustyszat. Już na drugi dzień przycisnat naczelnego prezesa Księstwa $i$ żadat tego funduszu. Pan Willamowitz zrobil wielkie oczy, ale oświadczyt, ze procentów od 60 lat zalegtych dać nie może, bo byly obracane na «inne cele».

Teraz dopiero można bylo dojść tego, skąd się te pieniadze wzięty. Arcybiskup Dunin szedl $w$ poczatkach swoich rzadów bardzo na rękę pruskiemu rzadowi $i$ zgodzit się na to, że jego klerycy będa mieszkali $w$ osobnym konwikcie we Wroclawiu i tam na uniwersytecie będa uczyli się teologii. Na ten konwikt przeznaczył król pruski 90.000 talarów z «własnej szkatuly». Układ byl gotowy $i$ Dunin mial go podpisać we Wroctawiu, wracajac $z$ wód na Ślasku. Kiedy jednak tam przybyt, otrzymat z rak jednego z kanoników wrocławskich monitum z Rzymu - i pakt zerwat. Pieniadze leżaly odtąd w Poznaniu...

Ministeryum zgodziło się teraz na to, aby Arcybiskupowi Stablewskiemu oddać ten fundusz (270.000 marek), ale stanowczo oświadczyto, że nie dostanie ani feniga więcej. Zostały więc wygotowane plany. Postano je do Berlina, ale stamtad jakoś nie wracaly. Znaleziono różne wady i blędy i rzecz szła znowu w odwtoke. Zdarzyło sie, że Arcybiskup wybrat się do Gniezna. Pociag zatrzymuje się na matej stacyi, tak zw. Tamie Garbarskiej. Tam stat i czekal śp. Franciszek Dobrowolski, redaktor „Dziennika Poznańskiego”. Z zaciektego liberata przerobit się $w$ szkole Stablewskiego na «klerykała», bo zrozumial, ze Prusacy dawnoby już byli Wielkopolan zjedli, gdyby ich nie trzymat katolicyzm. Celsissime - szepnat Dobrowolski - wczoraj była w Malborgu mowa. Nowy kurs się rozpoczyna. Trzeba się spieszyć, bo seminaryum nie dadza. Tego jeszcze dnia byt sekretarz arcybiskupa X. Stryjakowski, w Berlinie. Plany byly w ręku radzcy ministeryalnego budownictwa, na szczęście katolika z nadreńskich prowincyi. Ten zrozumial, o co chodzi - i podpisat.

Dla nowego gmachu przeznaczono ogród bursy Szołdrskich. Kapituła przekazała sąsiednie nieruchomości z przyległościami, arcybiskup - przyległą część ogrodu pałacowego, wykupiono też sąsiednią nieruchomość Stanowskich na Zagórzu. Po dwóch latach prace budowlane dobiegły szcześliwego końca.

W czwartek dnia 19 listopada 1896 roku odbyło się uroczyste poświęcenie nowego gmachu i inauguracja studiów. Miejscowa prasa poświęciła temu wydarzeniu wiele uwagi. Przede wszystkim „Kurier Poznański”, dziennik założony w roku 1872 przez ultramontańską grupę ziemian, przeznaczony głównie dla ziemiańskiej inteligencji, nawołujący do zgody w interesie Kościoła i narodu, wydawany przez Ludwika Merzbacha pod redakcją Teodora Żychlińskiego. Poświęcano tu dużo miejsca sprawom Kościoła, a w serwisach informacyjnych problematyka kościelna bywała niejednokrotnie dominująca. Nazajutrz po inauguracji, w wydaniu piątkowym z 20 listopada ukazał się tu obszerny materiał (rozpoczynający się na pierwszej stronie gazety) pt. Uroczystość otwarcia nowe semina- 
ryum duchownego w Poznaniu. Tekst rozpoczynał się zdaniem: Prawdziwe «grande» to «opus», którego dokonal nasz Najprzew. X. Arcypasterz przez wybudowanie nowego gmachu na pomieszczenie seminaryum dla kleryków. Obszerny ten artykuł zawierający kilka stron druku (szczegółowa relacja z uroczystości, ale i m.in. przemówienia obszerne in extenso arcybiskupa, regensa Jedzinka i notabli, szczegółowy opis domu i kaplicy) kontytuowany był w numerze następnym. Również „Posener Tageblatt” (nr 545 z tego roku) zauważył to wydarzenie w artykule Einweihung des Klerikerseminars.

Na szczególną jednak uwagę zasługuje relacja bardzo obszerna w trzech kolejnych, grudniowych numerach „Przewodnika Katolickiego” (nr 48, 49, $50 \mathrm{z}$ roku 1896), który przedstawiał się czytelnikom jako „Pismo dla Rodzin, Bractw i Stowarzyszeń Katolickich". Pismo to dopiero raczkowało (żyło dopiero drugi rok). Było bardzo skromne, lichy papier bez ilustracji, za to winieta w tamtym stylu, finezyjna. Założycielem „Przewodnika” był arcybiskup Stablewski a redaktorem został ksiądz Józef Kłos. Artykuł pt. Nowe Seminaryum duchowne w Poznaniu jest nie podpisany. Czy jego autorem był sam redaktor ks. Józef Kłos? Tekst poniżej przedstawiony, jest odtworzony bez zmian z wymienionego wyżej „Przewodnika Katolickiego", z zachowaniem starej pisowni i interpunkcji*.

\section{NOWE SEMINARYUM DUCHOWNE W POZNANIU}

\section{I}

Prawdziwie wielkiego, wiekopomnego dzieta dokonal nasz Najprzewielebniejszy X. Arcypasterz wznoszac wspanialy gmach seminaryum duchownego, odpowiadajacy wszystkim wymaganiom nauki i zdrowotności. Bardzo dotkliwie odczuwano dotad brak seminaryum wystarczajacego na pomiesz-

* J. Nowacki: Dzieje archidiecezji poznańskiej. T. 2: Archidiecezja poznańska w granicach historycznych i jej ustrój. Poznań 1964 s. 702-724. - M. Banaszak: Poczqtki kolegium jezuickiego i seminarium diecezjalnego. W: Sacrum Poloniae Millenium. T. 10. Rzym 1964 s. 505-516. - L. Piechnik: Seminaria diecezjalne prowadzone przez jezuitów od XVI do XVIII wieku. Kraków 2001 s. 69-86. - W. Chotkowski: Floryan Oksza Stablewski, arcybiskup gnieźnieński i poznański. Wspomnienie pośmiertne. Kraków 1906 s. 31-34. - J. Kłos: Arcybiskup Floryan Oksza Stablewski. Poznań 1907 s. 55-91. - S. Lukomski: Arcybiskup Stablewski. Kartki z jego zycia i dziatania. Poznań [1933] s. 15-17. - J. Pietrzak: Florian Stablewski 1891-1906. W: Na stolicy prymasowskiej w Gnieźnie $i$ w Poznaniu. Szkice o prymasach Polski w okresie niewoli narodowej i w II Rzeczypospolitej. Praca zbiorowa pod red. F. Lenorta. Poznań 1982 s. 254-256. - K. Śmigiel: Florian Stablewski arcybiskup gnieźnieński i poznański (1841-1906). Gniezno 1993 s. 100-106.

Z wymienionych pozycji wyłuskałem szereg informacji, które podałem wyżej i które wydały mi się pożyteczne w tym szkicu (szczególnie opracowania J. Nowackiego, W. Chotkowskiego i K. Śmigla), którego zamiarem jest wprowadzenie czytelnika do zamieszczonego niżej tekstu in extenso z roku 1896. 


\section{Foto}


czenie wszystkich kleryków. Musiano sobie przez dlugie lata pomagać w ten sposób, ze przeznaczano mieszkania klerykom $w$ dwóch lub trzech nawet osobnych miejscach. Że na tem nie ucierpiato wieccej dobre wychowanie duchowienstwa, to zawdzięczamy chyba tylko czuwajacej nad nami lasce Bożej. W każdym razie byt to stan nienormalny, bo zbywato na jednym $z$ najważniejszych warunków dobrego prowadzenia i kształcenia przyszlego kleru, stosownem, odpowiadajacem przepisom Kościolami potrzebom czasu umieszczeniu młodych lewitów. Osiagnięcie, tej jednej rzeczy, to jest zjednoczenie wszystkich czlonków zakładu w jednym gmachu, stanowi już samo nieoceniona zdobycz na polu wychowania kleru.

Wielka jest bez watpienia radość Najprzew. X. Arcybiskupa, że mu pozwolit Pan Bóg dokonać tego wielkiego dziela. I sqdzimy, że cala dyecezya tę radość swojego Arcypasterza szczerem sercem podziela. Wszakże to dla dobra tej dyecezyi pracować będa ci kaplani, którzy w nowowybudowanem seminaryum, maja czerpać skarby wiedzy, niespożyte zapasy goracej mitości Boga i bliźniego.

Uroczyste poświecenie tego nowego seminaryum duchownego w Poznaniu odbyto się $w$ czwartek 19 listopada, $w$ dzień św. Elżbiety.

$O$ godz. 81/4 zajechat Najprzew. X. Arcypasterz przed nowa kaplice seminaryjskq. Tu oczekiwało i przyjęto Jego Arcybiskupiq Mość całe duchowieństwo, majac na czele X. kanonika Jedzinka, regensa seminaryum. Wstepujacego w progi kaplicy $X$. Arcypasterza powital chór odśsiewaniem antyfony: „Ecce sacerdos magnus" (Oto kaplan wielki) pod kierownictwem p. dyrektora Dembińskiego. Po mszy św., która odprawit w asyście X. kan. Jedzinka i radcy Gimzickiego z Wielichowa, wygtosit X. Arcypasterz od oltarza mowe nacechowanq glębokq wdzięcznościa ku Panu Bogu za dokonanie dzieła, które ma się stać źródlem blogostawieństwa dla dyecezyi w dhugie pokolenia. Staraniem Jego Arcybiskupiej Mości bylo, jak sam to oświadczyl, stworzyć seminaryum w myśli i duchu Kościola katolickiego. Z tego seminaryum odtad maja kaplani wynosić owe święte uczucia względem Boga i ludzi, które stanowiq niejako tlo życia pobożnego, tem bardziej życia kaplańskiego: świętość, zamilowanie modlitwy, naukę $i$ wielka milość do swoich owieczek.

Na mowe Najprzew. X. Arcypasterza, zawierajaca cenne wskazówki, a mianowicie dla alumnów, do których byly skierowane, odpowiedział regens seminaryum X. kan. Jedzink, wyrazajac w imieniu XX. Profesorów i kleryków z głębi serca wdzięczność za to dobrodziejstwo, które Pan Bóg wyświadcza za pośrednictwem X. Arcypasterza całemu zakładowi, w którem to dobrodziejstwie pasterska Jego ku owieczkom miłość się uwieczniła.

Po udzieleniu arcypasterskiego blogoslawieństwa rozpoczęla się następnie sama uroczystość poświęcenia gmachu seminaryjskiego. Wśród śpiewu 
naszej starej pieśni „Boga Rodzico” ruszyl pochód składajacy się z 150 księży $i$ wszystkich kleryków. Na końcu poprzedzony przez obydwóch Najprzew. XX. Biskupów-Sufraganów Likowskiego i Andrzejewicza i przez obie Prześwietne Kapituly postępowal Najprzew. X. Arcypasterz, pokrapiajac woda święconq mury seminaryjskie $i$ święcac wszystkie pokoje i sale.

Druga część uroczystości, otwarcie seminaryum odbyto się na pięknej sali seminaryjskiej w obecności naczelników naszych władz świeckich. Uroczystość rozpoczęla się odśpiewaniem kantaty przez chór archikatedralny. Poczem przemówil Najprzew. X. Arcypasterz po łacinie do Przewielebnego $X$. Regensa $i$ XX. Profesorów. W dlugiej tej mowie przedstawil Dostojny Mówca historya naszego seminaryum duchownego (która to historyę opiszemy w następnym numerze „Przewodnika”). Na końcu zwróciwszy się znowu do XX. Profesorów i oddajac im to nowe seminaryum, $w$ którem wraz z klerykami, poruczonemi swojej opiece $i$ swoim staraniom mogq się oddawać stużbie Bożej, tak mówił do nich:

,Do Was teraz należy, abyście prawidlowo i pilnie korzystali z daru Bożego w pracy nad poważnem $i$ wzniostem dziełem, do którego Was Opatrzność Boska laskawie powolała. Miejcie w pamięci, że Waszej pieczy $i$ Waszemu staraniu powierzeni sa przyszli pasterze i kierownicy dusz nieśmiertelnych; ale z drugiej strony, że niepewność czasów i rzeczy z dnia na dzień niemal staje się większq $i$ niebezpieczna.

Korzystajcie zatem z tego, rzucajcie w serca powierzonej Wam młodzieży ziarnka nauki Jezusa Chrystusa, aby za jej pomoca $i$ sama zdołala zawsze rozróżnić prawde od fałszu i umiała pouczać skutecznie wierny lud, który jej kiedyś będzie powierzony, ażeby żadnym błędem lub namiętnościa nie dat się sprowadzić z drogi wskazanej przez Zbawiciela, ani nie dat się unieść tej strasznej burzy, która zerwawszy się przeciw Kościolowi i państwu, uderza dziś na nie z groza $i$ wściektościa. Krzatajcie się, abyście mlodzież tę wychowywali na kaptanów według myśli Bożej (1 Reg. 2, 35), którzyby pałali prawdziwa miłościa Boga, a nie wahali się nigdy i nie mieli watpliwości, skoro chodzi o chwate Jego: którzyby pałali prawdziwa miłościa bliźniego a nie lękali się trudów i mozolów, czy to w obronie dóbr doczesnych, czy mianowicie $w$ staraniu o zbawienie wieczne dusz im powierzonych".

Następnie przemówit X. Arcypasterz po niemiecku, jak nastęuje:

Czuję się szczęśliwym, iż danem mi jest widzieć w tej sali przy niniejszej uroczystości reprezentantów najwyższych dostojeństw świeckich naszej dzielnicy $i$ witam Wasze Ekscelencye $i$ Was wszystkich, przezacni Panowie, radosnem i wdzięcznem sercem, także dla tego, ponieważ obecność Panów daje publiczne świadectwo, iż Panowie odczuwacie doniostość religii dla dobrobytu państwa, dla szczęścia wszystkich jego obywateli i dla bezpieczeństwa 


\section{Foto}


tronu w tem glęboko poważnem znaczeniu, jakiemu Jego Cesarska Mość niedawno jeszcze temu dat tak znakomity i jędrny wyraz. Bunt przeciw wszelkiej władzy tak duchownej jak świeckiej szerzy się na coraz to większej linii, $z$ coraz bardziej ogarniajaca $i$ wzrastajaca potega, gdy tymczasem $w$ obec tego wielokrotnie pomaga zaślepienie $i$ namiętność z matodusznych przyczyn do podkopywania z jednej strony powagi Kościoła, z drugiej wybiera momenta rozdwojenia i rozterki, zaostrza przeciwieństwa i to w okresie dziejów, w którym chodzi może o „być albo nie być" catego dotychczasowego porzqdku państwowego i społecznego. Dla tego dobroczynnie dziala wszelkie publiczne uznawanie religii, której postannictwo zbawienne sięga daleko po za ten świat, także pod względem jej zadań ziemskich $i$ znaczenia.

Błagam Boga, aby to nowe seminaryum przez gruntowna nauke, przez pielegnowanie zamiłowania tejże stało się szkoła dzielnych i godnych wspótpracowników przy wielkich zadaniach naszych czasów, aby pozostało dla wielu pokoleń rozsadnikiem tych wszystkich obowiazków, które udzielaja zbawienia wiecznego, doczesnego dobra ludzi, utrwalaja porzadek i bezpieczeństwo państwa.

$W$ dalszym przebiegu Swojej mowy sktada Najprzew. X. Arcypasterz serdeczne podziękowanie tym wszystkim, którzy w jakikolwiek sposób przyczynili się do wzniesienia i przyozdobienia nowego gmachu, na pierwszem miejscu wyrażając najgłębszq wdzięczność Najjaśniejszemu Panu, Jego Cesarskiej Mości, iż raczył przez wielki datek przyłożyć ręki do tego dzieła. Zakończyl X. Arcypasterz przemówienie stowami: Retribuat omnibus Deus omnipotens. - Niech odplaci wszystkim Bóg wszechmogacy!

Po przemówieniu naczelnego prezesa, pana barona Willamowitza, który jako przedstawiciel wladzy państwowej dorzucił jeszcze życzenie, aby ten nowy gmach stal się rozsadnikiem nie tylko prawdziwej bojaźni Bożej, ale także poszanowania dla praw $i$ wiernopoddańczości, zabrał jeszcze raz głos Przewielebny X. kanonik Jedzink, regens seminaryum, $i$ w pięknej lacińskiej mowie wyraził najprzód radość swoja, że oto ,zaśwital nam dzień od dawna już upragniony, który wielu przed nami pragnęlo ujrzeć, a nie ujrzeli, dzień najuroczystszy, w którym kolegium nasze kościelne z najglębszego poniżenia podnosi się do nowego już zycia porzqdku i przyozdabia się wszelkiemi środkami do jego wykończenia zastósowanemi, aby się wydało godnem imienia seminaryum duchownego". - Przypomniawszy, jakie zadania maja seminarya duchowne i jakie zastugi ich wobec zbawienia dusz i porzadku publicznego, zwrócil się mówca do X. Arcypasterza i tak zakończyt:

„,Witam Cię przeto, Najdostojniejszy X. Arcypasterzu, tego dobrodziejstwa sprawce, najlaskawszego fundatora nowego gmachu, w którym dzisiaj 


\section{Foto}


uroczyście ustawiteś katedrę dawnej szkoły dyecezalnej i imieniem całego kolegium profesorów $i$ wszystkich alumnów podziękowanie Ci skladam, że po usunięciu przeszkód znojnej pracy takie nam wyświadczyleś dobrodziejstwo. Oby nowe seminaryum, pod Twojemi auspicyami otworzone, przy pomocy Boskiej laski, było ozdoba dyecezyi, siedliskiem nauki i cnoty; oby było matkq wiernych sług, źródlem pociechy dla Ciebie przez czas najdhuzszego rzadu Twego pasterskiego nad owieczkami. Z Twojego rozkazu przerwanq na dhuższy czas prace jak najchętniej podejmujemy na nowo, przezacnq matkę z nowa milościq $i$ z zapalem przyciskamy do serca.

Adjutorium nostrum in nomine Domini".

Cała uroczystość zakończyła się wspólnym obiadem w obszernym nowym refektarzu seminaryjskim. Wśród przebiegu uroczystości nadeszly rozmaite telegramy, z których wyszczególniamy trzy:

Telegram od Ojca św., który wyrazil swoje radość z powodu otwarcia nowego seminaryum, a przesytajac błogosławieństwo raczyl zezwolić, aby seminaryum nosito Jego imię.

Najjaśniejszy Pan zaś raczyt telegraficznie za wyrazy holdu podziękować wraz z życzeniem, aby nowe seminaryum stało się szkoła cnót, które zdobia wiernego syna Kościola i państwa. Także

J. E. Kardynat Ledóchowski przestat serdeczne życzenia dla seminaryum i Najprzewielebniejszego X. Arcypasterza.

\section{II}

Kto czytal w przeszlym numerze opis poświęcenia i otwarcia nowego seminaryum duchownego w Poznaniu, temu moglo się latwo nasunać takie pytanie, jak też wygladała sprawa seminaryam $w$ dawniejszych czasach, czy nie byto zaklada, w którym by się ksztatcila mlodzież poświęcajaca się stanowi duchownemu? Czy dawniejsi biskupi poznańscy tak lekkomyślnie pomijali tę ważna sprawe $i$ nie dbali wcale o to, aby stworzyć instytucya w myśl i duchu Kościoła katolickiego celem dobrego wychowania przyszlych kapłanów?

Nie, zarzut taki bytby nieshuszny. Owszem, od najdawniejszych czasów biskupi poznańscy nie spuszczali z oka tej wielkiej sprawy. Warto prawdziwie poznać koleje, jakie przechodziło nasze seminaryum duchowne, i dla tego podajemy dziś historya poznańskiego seminaryum duchownego.

Od samego poczatku Kościoła poświęcano bacznq uwage wychowaniu i ksztatceniu duchowieństwa. Zaledwie Kościót zostat wyzwolony z więzów niewoli $i$ wyszedl $z$ katakumb, lochów podziemnych, $w$ których przez trzy wieki musiat się ukrywać, aliści papieże $i$ biskupi zabrali się do dobrego wychowania swoich mlodych lewitów. Taki św. Euzebiusz lub św. Ambroży 
osobiście kierowali nauka i czuwali nad cnota młodzieńców, którzy przygotowywali się do przyjęcia godności kapłańskiej. Przyszhy potem czasy zamieszek, po owych wiekach, które wydaty tylu uczonych $i$ świętych, biskupów i kaplanów, zalegla nad Kościolem Chrystusowym chmura ciemności: Kapłaństwo nie stato na wysokości swojego zadania, nastal ogólny upadek życia kościelnego, w rodzinach chrześcijańskich zjawiły się rozdwojenia. Wychowanie kleru bardzo wówczas nie domagalo. Dopiero sobór trydencki odnowit obowiqzek kształcenia młodych lewitów w osobnych zakładach. Jeden byt mianowicie maż wielkiej świętości i gorliwości, którego życiorys podat "Przewodnik” w zeszlym roku, a który wolę Kościoła natychmiast w czyn zamienit. Byz to św. Karol Boromeusz, arcybiskup medyolański. On pierwszy zaprowadzil w swojej dyecezyi seminarya, odpowiadajace przepisom Kościola, on też nosi nazwę ,Odnowiciela” życia seminaryjskiego.

Jak bylo w tym czasie u nas? Staranność i gorliwość biskupów poznańskich $w$ najdawniejszych juz czasach urzadzała zaklady, w których przyszli duchowni odbierali stosowne wyksztalcenie. Stal wówczas na dzisiajszym Nowym Rynku kościót św. Maryi Magdaleny a przy tym kościele znajdowata się szkoła parafialna, w której mtodzieńny zapoznawali się z poczatkami nauki, mianowicie z językiem lacińskim. Skoro tę szkołe parafialna ukończyli, przechodzili do wyższej szkoły katedralnej celem dokończenia studyów i uzupetnienia wykształcenia. Byt zaś w owych czasach zwyczaj, że jeden z kanoników katedralnych, których bywato kilkudziesięciu, zwany scholasta, wykladał obok innych gatęzi wiedzy teologia święta. Zdolniejszych tylko mlodzieńców, albo takich, którzy chcieli zdobywać sobie większe zapasy wiedzy, posylano do Krakowa lub na wyższe szkoly do Wloch. Tak bylo aż do szesnastego wieku.

W poczatku szesnastego wieku nastapita wielka zmiana. Jan Lubrański, biskup poznański, ażeby podnieść ogólny poziom wykształcenia i oświaty, zalożyl w Poznaniu w roku 1519 zaklad, który otrzymal nazwę Akademii Lubrańskich. Wyktadano tam rozmaite nauki, filozofia, matematyke, prawo, glównie jednakże pielęgnowano nauki teologiczne, tem więcej od tej chwili, kiedy owe wyższa szkołę katedralna, gdzie pobierali dawniej wyksztatcenie, teologiczne klerycy, zamieniono na prosta szkote parafialnq.

Byly to smutne czasy zaciętych sporów religijnych. Niezgoda wszystko rujnuje. To też na owych sporach religijnych, przyniesionych do nas z zagranicy, ucierpiata znacznie Akademia Lubrańskich.

W tym właśnie czasie sobór trydencki wydat rozkaz do wszystkich biskupów, aby starali się o zakładanie seminaryów dyecezalnych dla kleryków. Byt wtedy biskupem poznańskiem Adam Konarski. Tenże niebawem zabrat się do wypetnienia tego rozkazu. W testamencie swoim zapisat na seminary- 


\section{Foto}


um olbrzymia $w$ owych czasach sume 5000 złotych. Już w roku 1581 znajdujemy alumnów dyecezalnych umieszczonych w wielkim domu na ulicy „Bedelskiej”, która dziś nazywa się „Butelską”. Tam odbierali stosowne do swojego przyszłego stanu wyksztalcenie, a na ukończenie nauki posyłano ich do stojacego w bliskości przy dzisiajszej Farze kolegium Jezuitów.

Jednakże ten obrót sprawy nie zupetnie odpowiadat zamystom fundatora. Klerycy mieszkali daleko od katedry i biskupiej rezydencyi, biskup nie mógt należycie zakładu dozorować, a w końcu tak środki na utrzymanie seminaryum się zmniejszyły, że przez dziesięć przeszło lat nie było ani jednego kleryka.

$W$ tak smutnem polożeniu rzeczy powrócili biskupi poznańscy do tego zakladu, który swego czasu porzucili, i r. 1676 poruczono seminaryum dyecezalne opiece rektora kolegium Lubrańskiego; odtad pobierali alumni nasi stale naukę teologii w kolegium Lubrańskiego od teologów przysłanych przez Wszechnice Jagiellońska. Równocześnie zabezpieczyli na poczatku XVIII wieku biskupi poznańscy stały byt $i$ istnienie seminaryum. Biskup Krzysztof Szembek bowiem nadat mu prawa czyli statuty, a zarazem state wyposażenie, oddajac mu na własność trzy wsie, Piatkowo, Nadziejewo i Madre. Slusznie też nazywa się go zatożycielem, bo odtad seminaryum, pomimo że różne przechodziło losy, nigdy już nie upadło, ponieważ opierato się nie jak dotad na pieniędzach, ulegajacych zmianie czasów, lecz na wlasnych gruntach, które moghy ulec spustoszeniu, ale nigdy nie zupetnemu zniszczeniu. Biskup Teodor Czartoryski zaś oddal niedhugo potem sobie pod zarzad oddana pod Poznaniem wieś Biskupice, aby liczba profesorów mogla skuteczniej być powiększanq i uzupetnianq. W czasie tym mieścito się seminaryum $w$ domu wprawdzie nie obszernym, ale umyślnie dlań zbudowanym a położonym obok pałacu biskupiego, tuż przy moście Środeckim. Nie zbywato też na gorliwości i staraniach arcybiskupich, aby zakład dyecezalny, tak potrzebny na wychowanie i wyksztalcenie duchowieństwa, prosperowat. Mimo to przyszło pod koniec XVII wieku skutkiem ówczesnych zaburzeń politycznych i innych zajść niekorzystnych do tego, że wszystkie dochody seminaryum nie wystarczaly nawet na utrzymanie dwóch profesorów i pięciu kleryków.

Wnet wybuchly nawet niesnaski między akademiq Lubrańskich i akademiq krakowska, tak iż wspólna praca nadal nie bardzo była możliwa.

Nowy okres zaczyna się $w$ historyi seminaryum, kiedy biskup Antoni Onufry Okęcki wstapit na stolica biskupia. Za jego to rzędów zniesiono zupetnie akademiq Lubańskich. Biskup Okęcki wnet postaral się o to, ażeby gmach akademii przeszedt na użytek seminaryum dyecezyalnego. Skoro mu się to udało uzyskać, zaraz wyrobil na uposażenie i utrzymanie seminaryum solectwo grodnickie i trzy wsie, Bielawy, Januszewice i Ziemsko. 
Następnie nadat mu wyśmienita organizacya, w której zawarl jak najdokładniejsze przepisy, w jakim duchu młodzież duchowna ma być wychowa$n a, w$ jakich warunkach ksztalcona $i$ w jaki sposób sprawy wewnętrzne $i$ zewnętrzne samego seminaryum maja być prowadzone. Aby na tem pewniejszych podstawach oprzéc zreorganizowane $i$ wybornie urzadzone seminaryum, oddat je pod kierownictwo i zarzad duchownych kongregacyi misyjnej św. Wincentego à Paulo, których wówczas nazywano pospolicie misyonarzami, a którzy w owych czasach mieli nadzór nad większq cześsiq seminaryów królestwa i kierowali niemi z najlepszym skutkiem i powodzeniem. Zawiadywali oni naszem seminaryum przez 54 lata bardzo szczęśliwie. Kiedy zaś misyonarze opuścili nasze strony, a następnie i seminaryum dyecezyalne, a na ich miejscu ustanowiono duchownych świeckich jako profesorów zakladu, to i oni zarzadzali i kierowali niem wybornie, jak tego najlepiej dowodzi doniosty sposób działania i postępowania naszego kleru, wychowanego $i$ wyksztalconego przez nich.

Badżco badź postać biskupa Okęckiego góruje odtad obok biskupów Adama Konarskiego i Krzysztofa Szembeka ponad wszystkich innych opiekunów i dobrodziejów seminaryum poznańskiego.

Nastały znowu jednak cięższe czasy. Było to na poczatku naszego wie$k u$, kiedy zniesiono w naszej dzielnicy zakony. Braty one na siebie większa część ciężaru pracy nad zbawieniem duszy i dla tego zdawało się, że ich działanie dla wszystkich może być tylko pożytecznem. Niestety dla wrogów naszych ich zbożna praca byla sola w oku. Od razu musieli zakonnicy opuścić swoje stanowiska. W tej chwili też caty ciężar shużby Bożej i pieczy nad duszami spadt na barki duchowieństwa świeckiego.

Tego duchowieństwa świeckiego byto niestety bardzo mato. Jeżeli więc setki dusz nie miały ginać bez pomocy duchownej, trzeba bylo liczbe kaplanów powiększyć.

Pan Bóg, który czuwa nad potrzebami swojego Kościoła, sprawil to niebawem. Od roku 1840 liczba kleryków wzrastała z każdym rokiem.

Byto to radosnym objawem, ale $z$ drugiej strony nowe stad powstawaly ktopoty. Gmach bowiem seminaryjski obok tego wszystkiego, co potrzeba dla utrzymania $i$ zarzqdu domu, mógt pomieścić co najwyżej trzydziestu kleryków, a byto ich już nieraz sto dwudziestu. Trzeba więc było pomagać sobie $w$ inny sposób. Umieszczano kleryków w rozmaitych domach prywatnych poza seminaryjum, nieraz $w$ oplakanych stosunkach. Do seminaryum schodzili się oni tylko celem nauki i praktyk duchowych. Że się to nie przyczyniato do postępu $w$ dobrem, że owszem sprawa dobrego wychowania i ksztatcenia na tem cierpieć musiała, nad tem nie potrzeba się rozwodzić. 
Foto 
W roku 1821 wydata Stolica Apostolska sławna bulle, rozpoczynajaca się od słów „De salute animarum”. Ówczesny król pruski Fryderyk Wilhelm III pozwolit ja oglosić w państwie swojem i nadal jej przez to moc obowiazujacego prawa publicznego. W tej bulli przypomina znowu Stolica św. biskupom obowiazek zakładania seminaryów, w których by wychowywać, ksztatcić i utrzymywać się mogła taka liczba kleryków, jaka odpowiada rozległości dyecezyi i potrzebie, rzady zaś świeckie miały $w$ tem dziele biskupom przyjść w pomoc. Na mocy tej bulli domagat się ówczesny arcybiskup gnieźnieński i poznański X. Leon Przyluski pilnie i usilnie u władzy cywilnej przeprowadzenia tego rozkazu. Ale wytrwate $i$ ożwione pertraktacye piśmienne, toczone $w$ tej sprawie przez lat dwadzieścia, nie doprowadzily do szczęśliwego wyniku i skutku. Następca jego, dzisiajszy X. kardynat Ledóchowski podjal tę sprawe na nowo. Byly widoki dość pomyślne. Jednakże $w$ tym czasie wybuchła nieszczęsna walka kulturna. Arcybiskupa uwięziono $i$ moca wyroku najwyżsego trybunalu pozbawiono arcybiskupstwa, a seminaryum nie tylko że nie doczekato się nowego gmachu, ale nawet zupelnie rozwiazanem zostało.

Kiedy na stolicy arcybiskupiej zasiadl X. Juliusz Dinder, $i$ on sprawy seminaryum nie zaniedbat. Zaledwie jednak zdażył na nowo otworzyć seminaryum po kilkunastoletniej przerwie, śmierć przedwczesna przecięla pasmo jego życia i przeszkodzila dalszym jego staraniom o budowę nowego seminaryum.

W roku 1891 wstapil na tron arcybiskupów obecny nasz Najprzewielebniejszy X. Arcypasterz Floryan Stablewski. Już na drugi czy trzeci dzień po dokonaniu introdukcyi do katedry poznańskiej przybyz do seminaryum, kazat sobie przedstawić wszystkich kleryków i osobiście zwiedził wszystkie kaciki starego gmachu seminaryjskiego oraz nieznośnego pod względem zdrowotnym klasztoru pokarmelitańskiego, mieszkania większej części kleryków. To osobiste zapoznanie z wszystkiemi niedomaganiami dotychczasowego seminaryum wystarczyło, aby z cała energia podjać pracę $w$ tak ważnej sprawie zbudowania nowego gmachu seminaryjskiego wraz z odpowiednia kaplica. Jego to staraniom przypisać należy, że umyślnie w tym celu przybyt z Berlina minister oświaty, J. E. Bosse i sam się przekonal o gwaltownej potrzebie budowy. Udato się wskutek tego uzyskać od rzqdu na ten cel znaczna zapomoge $i$ odtad sprawa seminaryum na pomyślniejsze wstapiła tory.

„Po tylu przykrych i gorzkich - tak mówit X. Arcypasterz przy uroczystości otwarcia seminaryum - powiodlo mi się szczęśliwie zbudować ten gmach przestronny, wygodny $i$ wspaniaty, ku pielęgnowaniu pobożności i nauki świętej". 


\section{Foto}


Tak prawdziwie, czego tylu poprzedników Jego Arcybiskupiej Mości nie dokonato, tego dzięki Bogu dokonał szczęśliwie nasz Najprzewielebniejszy X. Arcybiskup Floryan! Zashuga Jego w tym względzie przetrwa wieki cale. Po wielu, wielu latach mury tego gmachu seminaryjskiego świadczyć będa o gorliwości Jego o dobro dyececyi. Chociażby nic innego nie przechowato Jego pamięci, to prawdziwie ,kamienie wołać będq". Zaś obok nazwisk takich opiekunów $i$ dobroczyńców seminaryum poznańskiego, jak biskupi Adam Konarski, Krzysztof Szembek, Antoni Onufry Okęcki, jaśnieć będzie $w$ historyi naszego seminaryum imię naszego Najprzewielebniejszego X. Arcypasterza Floryana!

\section{III}

W ostatnim tym artykule chcemy jeszcze podać laskawym czytelnikom opis nowego seminaryum duchownego i nowej odznaczajacej się pod względem piękności kaplicy seminaryjskiej.

Nowe seminaryum jest to wielki dwupiętrowy gmach o dwóch dlugich skrzydłach po obydwóch końcach. Przy wejściu w ulice Wieżowa stoi dawniejszy klasztor Karmelitanek $z$ kaplica. Zabudowania te stuzyly az do ostatniego czasu za glówne pomieszczenie kleryków. Dzisiaj mieszcza się w nich kuchnia, biblioteka, mieszkanie dla shuzby i dwa mieszkania dla profesorów. Dawniejsza kaplica ma być zamienionq na muzeum dyecezalne. Krużganek łaczy Karmel $z$ właściwym nowym gmachem seminaryjskim, który z drugiej strony podobnym krużgankiem taczy się z seminaryjska kaplica. Catość więc zabudowań stanowiacych seminaryum zajmuje prawie cata dlugość ulicy Wieżowej. Sam gmach seminaryjski ma z frontu 21 okien.

Po prawej stronie od wejścia z ulicy wchodzimy do sali rekreacyjnej, przeznaczonej na pobyt $w$ wolnym czasie, czytanie pism i skromnq zabawkę. Wielka to, obszerna, jasna sala, umeblowana z prostota, ale pięknie. $\mathrm{Na}$ kilku ozdobnych shupach spoczywa sufit, z którego zwiesza się wielki gazowy lampion, zapewniajacy wraz z bocznemi lampami dobre oświetlenie. Tuż za sala rekreacyjna znajduje się sala muzyczna.

$W$ lewo krótkim gankiem dochodzi się do refektarza, wspaniałej sali jadalnej, w której jedza klerycy i profesorowie z regensem na czele.

Audytorya czyli sale do wyktadów znajduja się na pierwszem piętrze: $z$ tych dwa sq mniejsze, a jedno bardzo obszerne, mogace wygodnie pomieścić 120 kleryków.

Główna część pierwszego i drugiego piętra zajmuja pomieszkania alumnów. Jest pokoi 63, z których trzydzieści urzqdzone na jednę osobę, trzydzieści na dwie, a tylko trzy pokoje na trzy osoby. Oprócz tego zarezerwowano 


\section{Foto}


jeszcze na trzeciem piętrze, na poddaszu 11 bardzo schludnych pokoików na przypadek, gdyby parter i dwa pierwsze piętra wystarczyć nie miaty.

Wielka ozdoba calego seminaryum, robiaca na zwiedzajacego bardzo mile wrażenie, sq piękne obrazy i staloryty, porozwieszane we wszystkich zakatkach seminaryum. Znajdujemy ich wiele w refektarzu, na gankach, $w$ audytoryach $w$ sali rekreacyjnej, w sali muzycznej mianowicie, gdzie zwraca uwage śliczny obraz przedstawiajacy śmierć Ananiasza i Safiry, padajacych trupem u stóp św. Piotra, i portret Biskupa Hozyusza. Najprzewielebniejszy X. Arcypasterz, będac ostatni raz w Rzymie, zakupil tam umyślnie w tym celu znaczna liczbe pięknych zabytków sztuki, pragnac, aby one nietylko zdobily ściany gmachu, ale także w mlodych alumnach wyrabiaty dobry smak i poczucie piękna.

Caty dom ogrzewany kaloryferami i oświetlony plomieniami gazowemi, zaopatrzony we wszystkie potrzeby wedhu najnowszych a zdrowotności odpowiadajacych wzorów, mile robi wrażenie.

Wysoki krużganek, na którego ścianach rozwieszone sa stacye drogi krzyżowej, prowadzi do kaplicy seminaryjskiej.

Kaplica seminaryjska to, można powiedzieć bez przesady, istne cacko. Już na zewnatrz wyróżnia się wśród otoczenia swego wysmukła gotycka wieżyczkq, strzelajaca $w$ niebo.

Cała kaplica przyozdobiona jak najwspanialej w tym celu, aby pięknościa ksztaltów podnosiła serca ku niebu, aby też swoja pięknościa pociagata serca pożadaniem tego piękna niebieskiego, które kiedyś za nagrodę ogladać mamy.

Styl budowy jest ostrolukowy. Dekoracya przeprowadzona $w$ formach do stylu zastosowanych $w$ najdrobniejszych szczególach. Szczególniej bija w oczy zlote kolumny pod lukiem tryumfalnym przy wejściu do presbyteryum, zdobne gotyckiemi liliami. Na wysokości póltora metra od ziemi rozpościera się wokoło barwny o żywym czerwonym kolorze kobierzec, a ponad nim bledna stopniowo owe żywe kolory aż się gubia w biatem sklepieniu pokrytem mnóstwem gwiazdeczek zlocistych. W presbyteryum zaś, opasajacy kobierzec jest o wiele bogatszy, koloru ciemno niebieskiego, ozdobiony porozwieszanemi złotemi winogronami.

Na szczególniejsza uwage w presbyteryum zastuguja trzy kolorowe okna, wspaniate $w$ kolorycie $i w$ wykonaniu. Jedno z nich przedstawia św. Jana Kantego, a jak napis umieszczony na podstawie świadczy, pochodzi z daru Najprzew. X. Biskupa Likowskiego, który kiedyś byl regensem seminaryum duchownego, drugie z wyobrażeniem św. Stanistawa Kostki, patrona młodzieży, ofiarowal obecny regens seminaryum, X. kanonik Jedzink. Trzecie 


\section{Foto}


okno w środku między dwoma pierwszemi, nad oltarzem, zawiera popiersie błogosławiacego Pana Jezusa.

Glównemi ozdobami kaplicy sq dwa obrazy malowane na ścianach i trzy ottarze znajdujace się $w$ kaplicy.

Zaraz na wstepie do kaplicy pada oko na fresk nad lukiem tryumfalnym. Przedstawia on u samego szczytu pod sklepieniem monstrancya z Najśw. Sakramentem $w$ obłokach, $w$ oświetleniu jasnych bijacych z niej promieni. Po obydwóch stronach $l u k u$, stopniowo ku dolowi widzimy najpierw aniołów, jednego z lira, drugiego śpiewajacego „,Pangue lingua”, wypisane na wstędze, a następnie Swiętych Pańskich, badź to $w$ adorujacej postawie, badź też $w$ zachwycie, którzy szczególnq odznaczali się czciq do Najśw. Sakramentu i dzieła o tej świętej tajemnicy pisali. Widzimy tam po prawej stronie św. Katarzyne Seneńska, św. Cyryla Jerozolimskiego, św. Hieronima, św. Grzegorza Wielkiego, na drugiej zaś stronie u samej góry św. Ambrożego, św. Tomasza z Akwinu, twórce przecudnych hymnów opiewajacych cześć Najśw. Sakramentu, św. Augustyna i św. Chryzostoma.

Najświętszy Sakrament to ognisko calego nabożenstwa $w$ kosiciele, to stońce około którego obracaja się wszystkie ceremonie i obrzędy kościelne. O tem maja pamiętać alumni, którzy codziennie na ten obraz patrzeć będa, aby od tego ognia mitości zapality się ich serca wedle życzenia Zbawiciela.

Drugi fresk, umieszczony w niży naprzeciw głównego wejścia od ulicy, przedstawiać ma owe scene z ewangelii, kiedy to Pan Jezus bogatemu młodzieńcowi na zapytanie co ma czynić, daje radę, aby porzucil bogactwa $i$ wszystko co posiada $i$ aby szedl za Nim. To pamiętne stowo Pana Jezusa: Veni et sequere me! Przyjdź i pójdź za mna! — ma być przyszlym kaptanom ustawicznem przypomnieniem, że trzeba iść za Zbawicielem, chociażby upat dnia miał wycieńczać siły, chociażby na drodze obowiazku czekała niewdzięczność a nawet potwarz, prześladowanie i męczeństwo.

Największym nakoniec klejnotem kaplicy sq trzy starożytne oltarze, sięgajace XV, XVI i XVII wieku. Pochodzq one ze zbiorów śp. X. proboszcza Münzenberga z Frankfurtu nad Menem, sławnego znawcy staroniemieckiej sztuki kościelnej. Znany ten kaplan rozporzadzajac wielkim osobistym majatkiem za cel życia sobie postawit, by stare, po części pousuwane przez protestantów z katolickich kościolów oltarze, przywrócić do stużby Bożej i nauce się przystużyć. To też po śmierci swojej, która przed pięciu laty nastapita, zastrzegt się testamentem, aby ulubionych zbiorów jego nie puszczano w handel, tylko, aby te oltarze chwale Bożej stużý mogly. — Kilka z nich widzieliśmy w katedrze frankfurckiej, inne po innych kościolach $w$ różnych stronach zdobia światynie, cztery zaś naszemu Najprzewielebniejszemu X. Arcypasterzowi udało się nabyć dla siebie, a tem samem i dla Archidyecezyi. 
Foto 
Jeden z nich mieści się $w$ prywatnej kaplicy pałacowej w Poznaniu, przedstawiajacy Pana Jezusa i Matkę Boskq ze św. Janem u stóp Jego, a na bokach rzeźbione figury męczenników św. i męczenniczek, następne zaś trzy znalazly umieszczenie $w$ kaplicy seminaryjskiej.

Pierwszy z nich z 16 wieku, wielki, najwspanialszy dla oka, bo na ztoconem, $w$ deseń rzeźbionem tle, przedstawia $w$ rzeźbie zwiastowanie Najświętszej Maryi Panny. Na klęczniku modli się Najśw. Panna a przed Nia postać Anioła Gabryela. Na prawem skrzydle tegoż tryptyku św. Barbara, na lewem zaśs św. Dorota, obiedwie figury także w rzeźbie. Gdy tryptyk zamknięty, widzimy malowane figury, świeże wprawdzie, ale $w$ charakterze do czasu zastósowane, św. Grzegorza W. na jednem skrzydle, a św. Fioryana, jako Patrona Najprzewielebniejszego X. Arcypasterza Ofiarodawcy tego oltarza, na drugiem.

Oltarz drugi, po prawej umieszczony stronie, przedstawia pięć tajemnic bolesnych różańca św., a mianowicie, część środkowa tryptyku na tle podobnie $w$ deseń zloconem, zawiera piata tajemnice w rzeźbie. Pan Jezus na krzyżu rozpięty, prześlicznie i naturalnie malowany, u stóp Matka Boska z Janem świętym. Skrzydta tryptyku, snać dorobione, choć w charakterze znakomicie zastosowane, zawieraja cztery poprzedzajace tajemnice bolesne. Trzeci wreszcie przedstawia śmierć i chwalebne ukoronowanie Matki Boskiej w otoczeniu Apostolów.

Tak się przedstawia kaplica seminaryjska w swojej wspaniatości i pięknych szczególach. I pędzel artysty-malarza i sztuka cała zlożyly się na to, aby wystawić godny przybytek Panu. Jest ona na pierwszem miejscu dzielem Najprzewielebniejszego X. Arcypasterza, który sam najpilniej krzatat się około jej wzniesienia i przyozdobienia. Niepomierna część zastugi spada także na obiedwie Prześwietne Kapituly i cate duchowienstwo dyecezalne, które pokryto koszta budowy wynoszqce kilkadziesiat tysięcy marek. Świadczy o tem napis umieszczony u glównego wejścia:

Archieppus Florianus

Utrumque Capitulum Metrop.

Clerus dioeces. hoc sacellum fundavere.

co znaczy: Arcybiskup Floryan, Obiedwie Kapituly metropolitalne, kler dyecezalny tę kaplice ufundowali.

W czasie swych przeszło stuletnich dziejów gmach seminaryjny dwukrotnie bywał zamykany.

W czasie pierwszej wojny światowej władze pruskie przeznaczyły go na szpital wojskowy. W roku 1919 po odnowieniu budynku i unowocześnieniu jego wnę- 


\section{Foto}




\section{Foto}


trza (centralne ogrzewanie, oświetlenie elektryczne) powrócił do swej funkcji pierwotnej. Także i tym razem prasa poznańska z radością przywitała ten nowy początek. „Kurier Poznański” z 12 lipca tego roku (nr 158) artykuł pt. Uroczystość otwarcia Seminarium Duchownego w Poznaniu rozpoczynal od zacytowania pierwszych zdań z inauguracyjnego przemówienia arcybiskupa Edmunda Dalbora: «Wiosna narodów», która przyniosła nam wolność utęskniona, darzy nas iście po królewsku. Najświeższy dar, to seminarium duchowne. Otwieramy je uroczyście po pięcioletnim zamknięciu. Także „Dziennik Poznański”, który już dawno wycofał się z pozycji liberalnych na pozycje umiarkowanego konserwatyzmu, te drugie narodziny zauważył wyraźnie (nie zauważył pierwszych). W numerze sobotnim z 12 lipca tego roku (nr 158), kończył swoją relację: Zakładowi, w którego murach mlodociane lata swe na naukach zastępy zacnych mężów o światlej glowie i szerokiem sercu spędzily, mężów zaiste opatrznościowych, którzy krzepili stowem i czynem w latach największego ucisku i prześladowania nas, podtrzymujac ogień ducha polskiego, życzymy, aby i nadal swe posłannictwo spetniat, z błogostawieństwem Bożem. A mlodzieńcom, poświęcajacym się temu petnemu zaparcia się zawodowi, by stali się godnymi swych poprzedników...

Druga, bolesna przerwa w funkcjonowaniu seminarium spowodowana została wybuchem drugiej wojny światowej. W dniu 4 października 1939 roku gmach seminaryjny został ostatecznie zamknięty przez gestapo. Rozlokowała się tu policja, a kaplica została zamieniona na magazyn. W styczniu i lutym 1945 roku gmach został zrujnowany.

Po wojnie arcybiskup Walenty Dymek przystapił energicznie do jego odbudowy, która w lipcu 1947 roku została zakończona. Nie odbudowano tzw. Karmelu, który stał na początku ul. Wieżowej. Rozebrali go Niemcy w roku 1940/41, projektując przelotową trasę. Na jego miejscu, po usunięciu nasypu pod trasę, zbudowano przeznaczony dla pierwszego roku alumnów mniejszy dom piętrowy. Jako alumn pierwszego roku mieszkał tam w roku 1955/56 także autor tego szkicu. Gdy powrócono do okupacyjnej koncepcji trasy przelotowej, ten nowy dom został rozebrany. Dobudowano nowy dom wzdłuż trasy połączony z głównym domem seminaryjnym.

Trzecia przerwa w funkcjonowaniu uroczyście otwartego w roku 1896 gmachu seminaryjnego, już się nigdy nie zakończy. Nie będzie trzecich narodzin, trzeciego seminaryjnego początku. Po stu siedmiu latach dzieło arcybiskupa Floriana Stablewskiego w lipcu 2003 roku zakończyło swój żywot ostatecznie jako dom seminarium duchownego w Poznaniu. Wielu alumnów opuszczających ten dom w uroczystość świętych apostołów Piotra i Pawła, czyniło to z nostalgią i ze świadomością że tu w tej roli już nigdy nie powróca. 
Dom pozostał. Zmienił funkcję. Pewnym zmianom - zgodnie z potrzebami nowego użytkownika, czyli Wydziału Teologicznego - ulegnie zapewne wnętrze domu. Przy tej okazji należało by przypomnieć, że odbudowany w roku 1947 gmach seminaryjny, nie został odbudowany do końca według kształtu architektonicznego przedwojennego. Wydawało się wtedy oczywiste, że należało dokonać odbudowy jak najszybciej, aby dom mógł powrócić do swej funkcji, do której został powołany. W ten sposób - niestety - gmach utracił zupełnie swoją zewnętrzną, neogotycką architekturę (ile stracił, można sobie wyobrazić patrząc na przylegający doń neogotycki seminaryjny kościół). Gmach między innymi został okrojony o trzecie piętro, zdecydowanej zmianie uległ fronton gmachu: nie ma obecnie wystającej partii wielkiego audytorium, zredukowanego do mniejszych rozmiarów, nie ma strzelistych neogotyckich detali i ornamentacji.

Piszący te słowa słyszał wielokrotnie $\mathrm{z}$ ust powojennych rektorów, szczególnie ks. rektora Aleksego Wietrzykowskiego: ten dom został odbudowany wedlug możliwości, jakimi wtedy dysponowaliśmy, archidiecezja czekała na seminarium, ale gdy przyjda lepsze czasy (to wyrażenie powtarzał wielokrotnie), a przyjda na pewno, musimy przywrócić mu wyglad pierwotny, bo to dzieło arcybiskupa Stablewskiego na to zashuguje.

Czy te lepsze czasy nadeszły?

W Poznaniu między innymi dla wielu zniszczonych przez wojnę lub prowizorycznie (i brzydko) po wojnie odbudowanych domów, te lepsze czasy szczególnie w ostatnim dziesięcioleciu nadeszły. Domy te nabrały nowego blasku w swej pierwotnej architekturze.

Piszący te słowa wyraża nadzieję, że obecnie nadszedł taki czas także dla 107-letniego gmachu seminarium duchownego, że nastapi jego zewnętrzna, pełna neogotyzacja, a zmierzającym ze śródmieścia w kierunku wyspy tumskiej i katedry ukaże się widok kościoła i gmachu seminaryjnego (obecnie Wydziału Teologicznego) w swej dawnej neogotyckiej szacie. 